\title{
Unique or universal? Mechanisms and processes of social change in post-socialist Warsaw
}

\author{
Magdalena GÓRCZYŃSKA ${ }^{1}$
}

\begin{abstract}
This paper aims at providing new knowledge about the processes and dynamics of socio-spatial changes in post-socialist cities through the example of Warsaw. As reference cities for comparison we use two other post-socialist capital cities, Budapest and Prague. Dynamics in urban space are investigated through (1) the socio-spatial differentiation of neighbourhoods; (2) the regeneration of old housing stock in the inner-city, as well as (3) differentiation of actors contributing to new housing construction. These processes influence residential mobility and shape significantly the spatial distribution of different social groups. Their impact on Warsaw has been assessed based on quantitative data. According to our research findings the process of property restitution, accompanied by privatisation and a growing mix of ownership structure, induced a unique process of fragmentation and social segregation at a micro-scale in the inner city of Warsaw, while the socio-spatial consequences of suburbanisation have been more similar to other post-socialist cities.
\end{abstract}

Keywords: social change, post-socialist city, urban regeneration, restitution, suburbanisation, ownership change, Warsaw

\section{Introduction}

At the beginning of the 1980s, Iván SzELÉNYI (1983) turned the attention to differences in the socio-spatial patterns of North American, as well as Western and Eastern European cities. At that time, the East European model was considered to be in between the American and Western European ones, admitting that the latter models were highly diversified. Also, the term of 'Eastern Europe' refers to a sort of uniformity, even though this region has always been highly diversified (WĘCŁawowicz, G. 1990). Although the socialist ideology based on the egalitarian principles of the distribution of goods, services and housing,

\footnotetext{
${ }^{1}$ Institute of Geography and Spatial Organization, Polish Academy of Sciences. Twarda 51/55, 00-818 Warsaw, Poland. E-mail: mgor@twarda.pan.pl
} 
was in favour of eliminating the extremities, the political and economic elite (even if not rich) enjoyed a lot of non-monetary advantages and privileges such as free car use, second homes, vacations, etc. (ENYEDI, Gy. 1992). In addition, Central European countries represented different variants of state socialism within the region (e.g. SELENY, A. 2006), which have also resulted in different paths of transformation since the demise of the socialist regime.

In the 1990s, the political and economic transformation opened new directions of social changes, including an increase in the level of socio-spatial disparities and income inequalities (ENYEDI, Gr. 1992), contributing to a more visible residential segregation (WĘcŁawowicz, G. 1998). For example, in the case of Czech Republic, segregation and spatial separation mainly concern the extreme groups: socially excluded Roma and well-off population living in gated communities (SÝKORA, L. 2009). The question arises if the contemporary processes and mechanisms of change are universal enough to explain the wide spectrum of phenomena occurring in different Central European cities. Bearing in mind the existing divergences between these cities, we can therefore ask to what extent these processes and mechanisms are alike.

In this paper, the primary attention is paid to processes and mechanisms of social change in Warsaw in comparison with two other Central European capital cities: Budapest and Prague. These processes will be analysed primarily through quantitative data. We use statistics for districts and communities collected yearly by the Central Statistical Office (Local Data Bank) as well as data of the Population Censuses 1988 and 2002 for enumeration units. The first source of data allowed us to analyse the spatial distribution of newly constructed dwellings, whereas census data could be used for the investigation of the spatial distribution of socio-professional groups in 1988 and in 2002 (according to enumeration units with more than 50 inhabitants). The Ward's minimum variance method was used to merge the clusters with the minimum between-cluster distance. Additional information concerning the number and the distribution of claims that set up the right of usufruct were obtained from the Office of Real Estate Management (Biuro Gospodarki Nieruchomości) in Warsaw. These quantitative data allowed us to grasp the social changes having taken place over the last twenty years and to provide some explanations about socio-spatial restructuring in Warsaw.

\section{Transformation of the post-socialist cities after 1990}

After the collapse of state-socialism, cities of Central and Eastern Europe have become the laboratories of changes, where the mechanisms and process of social change differ when compared to the Western cities. Socialist legacy can be perceived as a major factor that contributes to changes in the socio-spatial 
structures of the post-socialist cities. The national context, the consecutive stages of transformation and the pace of change vary between these countries, though the pathways of evolution are more or less dissimilar. It is not only the post-socialist heritage that influences changes, however, but also contemporary drivers. Thus, the current forces as well as the legacy of state-socialism trigger together processes of social change and contribute to the creation of new socio-spatial structures.

Many common elements contribute to the 'socialist heritage'. The extensively built up areas over the socialist period and vacant grounds mainly in the peripheral districts allow densification nowadays and the construction of new types of housing within the city limits. The former industrial zones provide also good opportunity for redevelopment nowadays. The future of the large housing estates remains an open question as their quality differs among the cities and countries.

The Central and Eastern European countries which were uniformly affected by nationalisation of private property after World War II have adopted different kinds of privatisation strategy after 1990 which in turn left its imprint on the socio-spatial processes. For instance in Hungary, restitution itself was rejected as a general solution in favour of financial compensation and direct sale of flats to sitting tenants (BLACKSELL, M. and BorN, K.M. 2002). In the Czech Republic, restitution began in early 1991 and by 1993 most of the property transfers were completed (Lux, M. and Mikeszova, M. 2012). In addition, the rights of the sitting tenants were unaltered and rent regulation preserved during the restitution process, while free market rents were allowed only for flats that had been vacated (Lux, M. and Mikeszova 2012; Lux, M. et al. 2012). However, in other countries, the restitution process led to shifting power relations and new polarization on the housing market, especially between tenants and landlords (Reimann, B. 1997).

The majority of Central and Eastern European countries have adopted the low-price strategy of sale of the public housing stock that contributed to the differentiation of owners in terms of their income (Clapham, D. 1995). As it was envisaged in the mid 1990s, the public housing sector shrank in size, became restricted to marginal households (CLAPHAM, D. 1995) and concentrated in traditionally low-status areas (Kovács, Z. 2012). Indeed, the privatisation of the public housing stock was considered as the most distinguishing feature of the transition, despite various mechanisms and regulations adopted in different post-socialist countries (BAROss, P. and STRUYK, R. 1993).

As a consequence, the private rental segment started to grow especially in East Germany and in the Czech Republic, whereas in other countries of Central and Eastern Europe, owner occupation expanded (Kovács, Z. 1999). The number of home-owners not only started to grow but also became quite diversified. Through the privatisation of public housing the share of homeowners with modest incomes was steadily growing which became another 
dimension of social differentiation. It is expected that many of this new poor owners in inner-city areas would be finally forced to move elsewhere when facing the problem of urban rehabilitation (Pichler-Milanović, N. 1994).

One of the most powerful processes that have evolved since the beginning of the 1990s, was suburbanisation. Even though, the move of people from central neighbourhoods to the peripheral estates existed even before and was labelled as a form of 'socialist' suburbanisation (Кок, H. 1999), after 1990 the process took new dimensions. The suburban zone of Prague attracted masses of better educated population with high income, which produced a dual social composition: rich newcomers and lower income, less educated indigenous inhabitants (SÝKORA, L. 1999).

In the metropolitan region of Budapest, similar processes of social upgrading and rejuvenation were observed, particularly in the 1990s (Kovács, Z. 2012). At the same time suburbanisation affected mainly the already better off and more attractive municipalities (Кок, H. 1999; Kovícs, Z. 2012) and, as a consequence, intensified socio-spatial differences in the metropolitan region. Private companies including foreign developers became soon the leading actors of new housing developments (SÝKORA, L. 1999; BodnAR, J. and MolnAR, V. 2010), as well as urban regeneration in the inner-city (Kovács, Z. et al. 2013). One the one hand, the diversification of housing developers increased the housing offer for sale, but on the other hand, the group of clients with appropriate incomes has shrunk.

The reinvestment and regeneration of inner city areas remained belated. First, the commercialisation of the historical core started both in Budapest (Kovács, Z. 1994) and Prague (SÝ́ora, L. 1999) in the early 1990s. In Prague, it involved the conversion of old tenement housing to offices and upmarket dwellings, generating gentrification and a socio-spatial change. However, gentrification as neighbourhood change did not exist in the early 1990s (SÝKORA, L. 1996) as this type of residential and social upgrading concentrated to small islands in the city centre (SÝKORA, L. 1999). Residential gentrification started in Prague as a property-development business fostered by foreign companies and targeted at a specific group of customers: mainly western foreigners (SÝKORA, L. 1999). In Budapest, physical and social upgrading (i.e. gentrification) also evolved in selected enclaves already in the 1990s, but it was generated mainly by local regeneration programmes and new housing developments (Kovács, Z. et al. 2013). Simultaneously, due to the dominance of the owner-occupied sector, a massive displacement of residents so typical in the West did not occur.

Having adopted the examples of Prague and Budapest, it may be claimed that these two cities, although labelled 'post-socialist', have undergone slightly different development since the early 1990s. As the existence of a single model for the post-socialist urban transformation has been challenged (Kovícs, Z. 2012), the question to be addressed here is: What kind of unique or universal processes have appeared in Warsaw since the political changes? 


\section{Changes in the socio-spatial structure of Warsaw since 1989}

To begin with it is important to underline that Central European cities underwent different levels of destruction during World War II which allowed greater or less opportunities for the socialist housing policy. Warsaw is exceptional in this field, with around $65 \%$ of its buildings destroyed (including the old town), particularly on the left bank of the Vistula river. The whole material losses incurred by the city and residents were estimated at 18.2 billion PLZ (Polish zloty) according to its value in August 1939, which is calculated approximately 45.3 billion USD today (Raport o stratach wojennych... 2004). The most significant destruction concerned buildings (8.4 billion PLZ) and equipment of private dwellings (5.3 billion PLZ).

The reconstruction of the city followed the socialist ideology based on the egalitarian principles together with centrally planned economy. The city also continuously expanded and between 1921 and 2006, its area quadrupled from $124.7 \mathrm{~km}^{2}$ to $517.2 \mathrm{~km}^{2}$ through the incorporation of surrounding areas (CZERwińsKa-JęDrusiaK, B. 2009). However, the spatial expansion of the city was not in harmony and peripheral districts were built-up extensively. Over the years, the scarce resources dedicated to the renovation and modernisation of the housing stock together with the slowing down of housing construction led to serious shortage of dwellings. Under the socialist regime, the role of land rent was almost completely eliminated, which resulted in a strong functional mix ${ }^{2}$.

Nowadays, in terms of housing, Warsaw is characterised by a mixture of buildings constructed in various periods which in turn provides differentiated housing conditions, and as a consequence, influences the spatial distribution of different socio-demographic groups. The old and deteriorated public buildings in the city centre (mainly on the right bank of the Vistula), the different generations of state-socialist housing estates as well as new gated and guarded estates scattered in the urban space, provide great variations in terms of their social composition. Simultaneously, the Central Business District (CBD) sprawls slowly from Śródmieście district towards the neighbouring district of Wola to the west (ŚLESZYŃSKI, P. 2004), a former industrial area, often labelled as 'Wild West'. Till the 1990s this area had been characterised by poorly developed and sometimes abandoned plots. Nowadays, due to new private (e.g. office, housing) and public investments the area undergoes massive redevelopment.

At the end of the socialist period the central districts of Warsaw already faced the problem of gradual depopulation together with a more accentuated division of social socio-economic groups (WĘCŁAWowICZ, G. 1998). One- and two-person households were more concentrated in the city centre

\footnotetext{
${ }^{2}$ Nevertheless, certain areas in Warsaw retained their significant land prices e.g. the inner city (TASAN, T. 1999).
} 
while the share of larger households grew in the peripheral districts and in the suburbs. At the same time, residential mobility of the elderly continued to decline, which resulted in a more pronounced division of 'young' and 'old' (WĘCŁAWOWICZ, G. 2002).

At the beginning of the $21^{\text {st }}$ century, the socio-spatial structure of Warsaw still retains its mosaic features, shaped during the socialist regime. Yet, the concentric and sectoral models tend to become more pronounced, thereby bringing the socio-spatial structure of the city more similar to other European cities (Sме̨ткошsкI, P. 2009). A recent study based on principal component analysis revealed that there are five major meta-features explaining the socio-spatial structure of Warsaw: demographic and family structure, socio-professional position, social marginalisation, population immigrated after 1988 as well as youngsters and students (SMĘTKOWSKI, P. 2009).

The concentric distribution of the first feature is a continuation of socio-spatial patterns which had already developed during state-socialism. The socio-professional position corresponds rather to sectoral distribution, which is similar to the patterns detected in the classic studies of socio-spatial structures in cities. The 'social marginalisation' feature takes mixed patterns of distribution with a couple of enclaves of poverty in the core city. Newcomers are usually overrepresented in the newly constructed housing estates while students are concentrated mainly in the vicinity of the higher education institutions. The stability of the socio-spatial pattern in Warsaw might be striking, as perhaps more revolutionary changes could have been expected after the demise of the socialist regime.

Although the level of social segregation in the post-socialist cities has always been lower than in Western Europe, in the case of Warsaw growing social polarisation, and housing differentiation induced sharpening social segregation (WĘCŁAwowicz, G. 1998). In the meantime, studies on the level of social segregation in Polish cities revealed that the indices had hardly changed between 1988 and 2002 (MARciŃcZAK, S. et al. 2012), or, they even showed a downward trend since 1978 (MARCiŃCZAK, S. et al. 2013). Despite the low values of the segregation indices, the increase of social separation has become more visible in the social and material space (WĘCŁAwowICZ, G. 1998). Thus, it may be assumed that social segregation strengthened at the very micro scale.

The aforementioned studies on social segregation concentrated mainly on the level of education which correlates with socio-professional position. However, it does not always correspond to the material wealth of the new social strata emerging after the demise of state-socialism. For instance, members of the 'intelligentsia' may fall into three different social categories: elite, middle class or poverty (WĘCŁAwowicz, G. 1998). I would be, therefore, cautious if indices of educational attainment are still reliable to measure social segregation in postsocialist cities. These doubts particularly concern the group with tertiary edu- 
cation level which may form middle class or upper class and in extreme cases also poverty group (young unemployed people with university degree). In other words, the indicators based solely on the level of education blur the picture of social segregation and probably reflect fewer dimensions than actually exist.

A significant change regarding the socio-spatial structure of Warsaw is clearly visible on the maps presenting the outcomes of hierarchical classification using the socio-professional categories in 1988 and in $2002^{3}$. As the socio-professional categories underwent modifications over this period, seven aggregated groups were used in order to assure comparability between 1988 and 2002. These included: (1) Legislators, senior officials and managers, (2) Specialists, (3) Office workers, technicians and junior managers, (4) Personal service workers and shop and sales personnel, (5) Farmers, (6) Blue-collars, plant and machine operators, and (7) Unskilled manual workers. In the cluster analysis six clusters were created (Figure 1).

As a second step the spatial distribution of the different clusters was analysed. First of all, it should be emphasised that only three out of the six

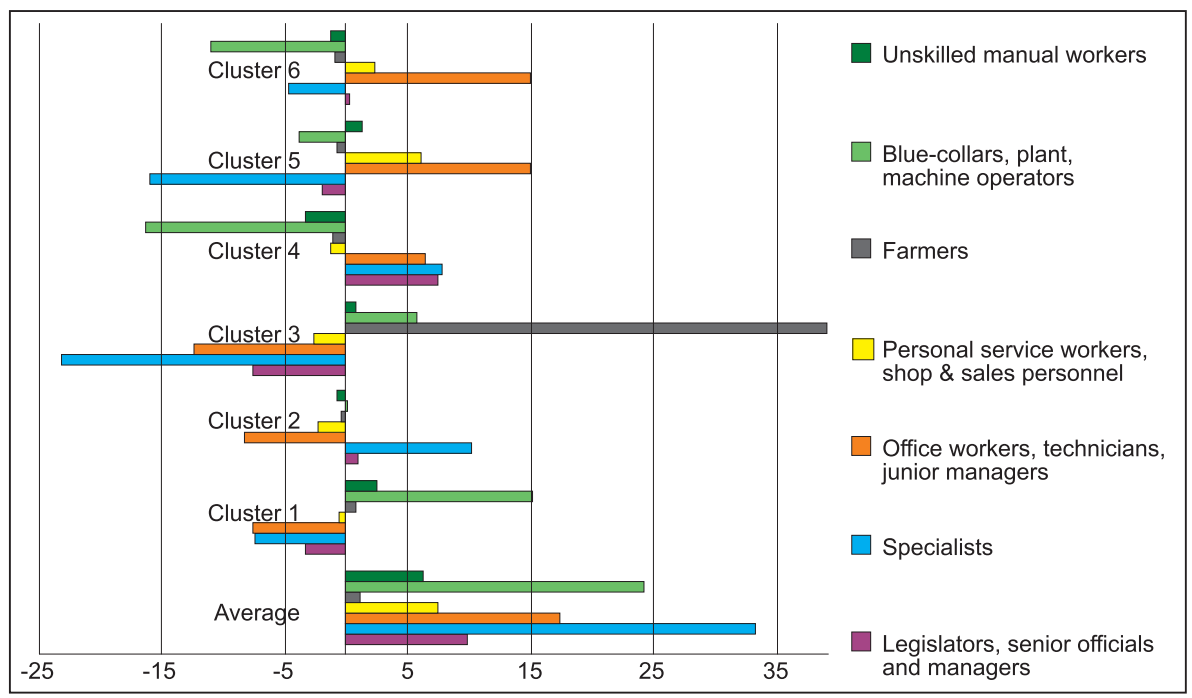

Fig. 1. Composition of clusters with regard to average. Source: National Census 1988, 2002, Central Statistical Office

clusters set up in the classification, appear both in 1988 and in 2002 (Figure 2). Secondly, while the cluster of "socially mixed areas with the overrepresentation of blue-collars" dominated in 1988 they appeared only as a few enclaves in the peripheral districts in 2002.

\footnotetext{
${ }^{3}$ Wesoła district was omitted as this area was only incorporated to Warsaw in 2002.
} 


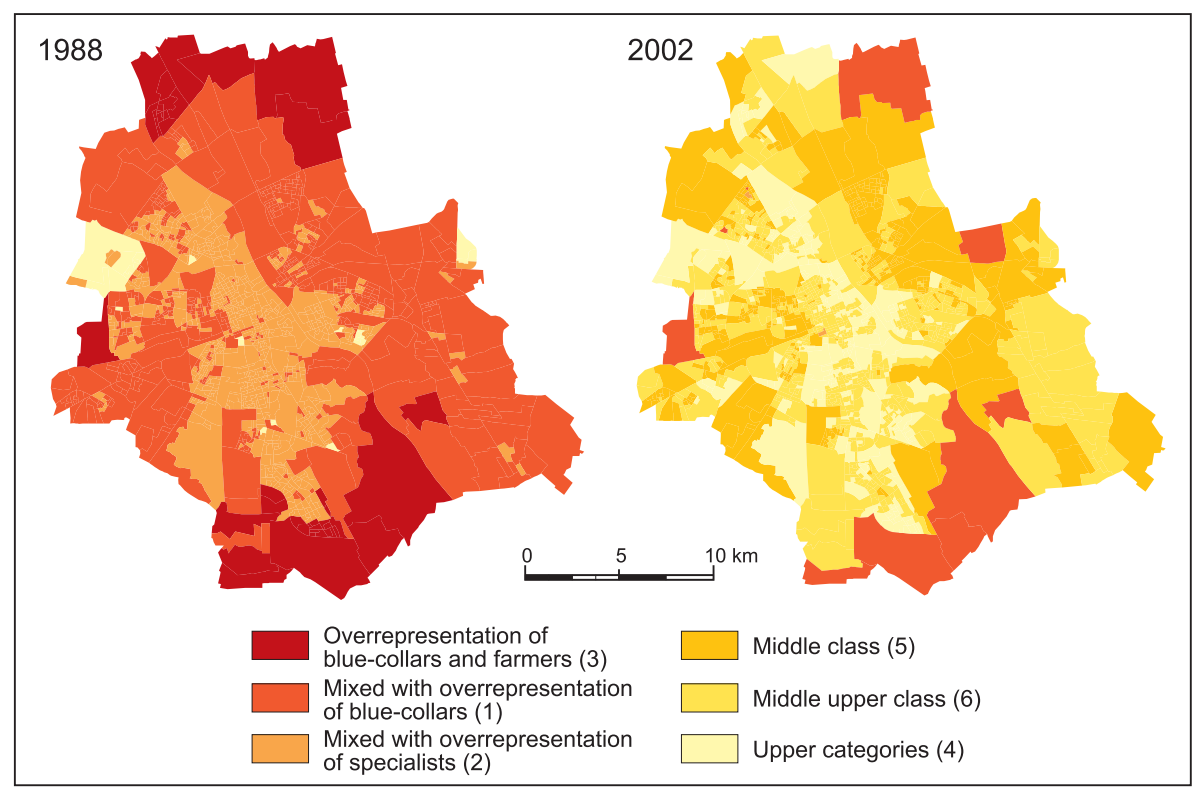

Fig. 2. Hierarchical classification by socio-professional categories in Warsaw in 1988 (a) and in 2002 (b). Source: National Census 1988, 2002, Central Statistical Office

At the same time, the cluster of "socially mixed areas with overrepresentation of specialists" which spread over the central districts of Warsaw from north to the south in 1988 almost disappeared by 2002 (only two areas left). Finally, the cluster with overrepresentation of upper categories appeared only in a very few statistical units in 1988, while in 2002 it almost completely replaced the cluster of "socially mixed areas with overrepresentation of specialists" in the central part of the city. These two maps illustrate exactly the profound changes that occurred in terms of cohabitation of different socio-professional categories, which contributed to stronger fragmentation at the micro scale than before.

In addition, our analysis revealed the increase of the middle categories and their diverse residential strategies in the city. On the one hand, this category occupied areas formerly dominated by blue-collars; on the other hand, the share of this group grew in the proximity of upper classes and areas with overrepresentation of specialists in 1988. Eventually, the spatial pattern of socio-professional clusters corresponds to the distribution of dwellings by their period of construction (STęPNIAK, M. et al. 2009). Therefore, the interdependencies between the age of dwellings and the socio-demographic features of their inhabitants continued to grow in Warsaw since the collapse of the socialist regime, not only at an urban scale (SМЕткоошsкI, M. 2009) but also at a micro-scale of quarters and statistical units (GórczYŃSKA, M. 2012b). 
Regarding the changes of the proportions of upper categories ${ }^{4}$ and workers categories ${ }^{5}$ in 1988 and in 2002, the growing dominance of the former group is particularly visible in the central part of the city, which could be interpreted as gentrification of the central districts (GóRCZYŃSKA, M. 2012a). Indeed, in certain areas the process corresponds to the gentrification (and its restrictive definition) described as invasion and succession of a neighbourhood inhabited originally by working-class households (BouRne, L.S. 1993), associated with rehabilitation and investment in the old buildings. However, data indicate that actually three distinct processes operate simultaneously: gentrification in the case of certain old buildings, embourgeoisement $t^{6}$ in the traditionally affluent areas and redevelopment linked to newly built residential buildings and gated communities (GórCZYŃsKA, M. 2012a).

These changes in the social composition of Warsaw took place mainly in the 1990s. Nowadays, we witness their continuation; however, the spatial outcomes of current changes are rather intuitive due to the lack of accurate statistical data. Nonetheless, with respect to the processes at work linked to the housing sector, a few conclusions may be drawn in order to assess the uniqueness or universality of mechanisms of social change that took place in Warsaw.

\section{Regeneration of the built environment: towards social upgrading?}

The processes of urban renewal and regeneration leading to social change occurred in Warsaw with some delay. According to the main actors of these actions, they may be divided into public and privately-led interventions.

Apart from the reconstruction of the capital city after World War II, publicly organised urban rehabilitation had not been planned before 2004 when the pilot programme of urban renewal was launched in four central districts ${ }^{7}$. In May 2008, the City Hall adopted the Local Programme for Revitalisation 2005-2013 (pl. Lokalny Program Rewitalizacji m.st. Warszawy). It comprised a variety of actions and operations taking place in almost all districts which prepared their micro-programmes of urban renewal. Those covered, among others, a wide range of actions towards socio-economic revival, development of tourism and culture on the basis of the existing cultural heritage and resources, improvements of security and communication possibilities within housing estates as well as integration of inhabitants and social inclusion.

\footnotetext{
${ }^{4}$ Legislators, senior officials and managers and specialists.

${ }^{5}$ Blue-collars, plant and machine operators and unskilled manual workers.

${ }^{6}$ The process known in French scientific literature as an increase in the number of upper social categories in the districts or communes traditionally characterised by a significant share of these categories (e.g. Pinçon, M. and Pinçon-Charlot, M. 1989).

${ }^{7}$ These pilot actions were co-funded by the European Regional Development Fund (within the Integrated Regional Operational Programme) and central budget.
} 
Concerning the built environment, the most visible actions of the public sector concentrated in certain old, municipal buildings of Praga Północ district. However, these operations were often criticised as being only 'façade renovation', while social problems of the local population remained unsolved. In the following years, Praga Północ district benefited from subsequent actions dedicated specifically to social issues in the framework of social revitalisation (e.g. the programme entitled: Block, backyard, tenant houses - revitalised neighbourhoods) and was also selected as one of the priority areas for urban and social revitalisation under the currently elaborated Integrated Programme for Revitalisation in Warsaw 2014-2020.

The second group of actions towards regeneration is initiated by private actors. First of all, often owners of single family houses undertake the renovation. This procedure is particularly visible in the old districts traditionally inhabited by more affluent population, e.g. Żoliborz, Mokotów (see also Bouloc, C. 2013). Secondly, another type of actions also slowly develops linked to the renovation of old buildings nationalised in 1945. After World War II nearly 40,000 properties were nationalised which made up around $94 \%$ of existing buildings and land in the city in 1939 . Then, the Decree on the public management of dwellings and rent control (1945), introduced

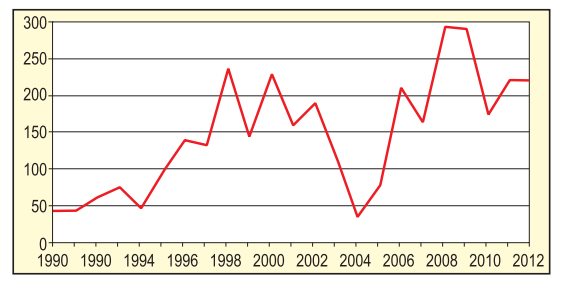

Fig. 3. The number of properties in Warsaw affected by restitution (1990-2012). Source: Biuro Gospodarki Nieruchomościami, Urząd Miasta Stołecznego Warszawy

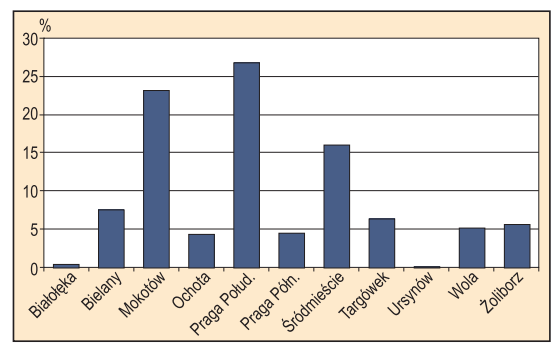

Fig. 4. The share of districts in the restitution process (1990-2012). Source: Biuro Gospodarki Nieruchomościami, Urząd Miasta Stołecznego Warszawy two other important tools: defined the rules concerning the average floor space per person in a dwelling, introduced "rent under special regime" (in Polish szczególny tryb na$j m u$ ) and pinpointed particular professional groups (needed in the city) that might have acquired a dwelling. The rent control was introduced and the criteria of population in dwellings adopted. All these actions limited the right to dispose of private property and strongly influenced the social composition of the pre-war buildings as well as the housing conditions of the population that time (GórCZYŃSKA, M. 2014).

The process of restitution of public properties commenced slowly already under the socialist regime, nevertheless, the number of claims accepted at that time remained very low. The process has quickly accelerated after the change of regime (Figure 3 and 4). According to the Office of Real Estate Management in the City Hall, the number of returned properties has been growing steadily and the process is particularly robust in the central districts. 
Not only do private owners recapture their properties, but they often sell them to private developers who possess sufficient financial resources in order to renovate these old and usually deteriorated pre-war buildings. There already exist examples of restituted buildings that have been completely renovated and transformed into luxury apartments for upper classes. Generally, high quality apartments in old buildings in Warsaw are rare and investors make use of this niche on the housing market. Thus, the demand for "apartments with a soul" grows despite the fact that their prices are among the highest in the city.

\section{New actors on the housing market}

The collapse of state-socialism has also influenced the group of actors providing new dwellings on the housing market. Till the end of the 1980s, housing cooperatives were the main housing developers but the situation has changed as they no longer benefited from favourable conditions as they did under Poland's planned economy (Herbst, I. and MuzioŁ-WęcŁawowicz, A. 1993). In general, housing construction at the beginning of the 1990s was very low.

Then, since the middle of the 1990s foreign (Scandinavian, Canadian, Israeli, American, and also Italian and German) housing developers have entered the housing market and diversified the housing offer, providing luxury apartments as well as quite large housing estates, more affordable, particularly in the peripheral districts (mainly in Białołęka). Since then, the share of dwellings constructed by housing cooperatives has further dropped in Warsaw: from $35.7 \%$ of newly constructed dwellings in 2002, to only $9.6 \%$ in 2012 (Local Data Bank, Central Statistical Office, 2014). At the same time municipal housing construction remained limited: only $2.8 \%$ of the newly constructed dwellings were built by public institutions in 2012 (Local Data Bank, Central Statistical Office, 2014).

The number of newly constructed dwellings steadily grows in the peripheral districts of Warsaw (Figure 5), as well as in the close suburban areas (Figure 6). Regarding new housing construction housing developers dominate in the central and the densely built peripheral districts of Warsaw. Whereas the share of individuals is higher in the districts situated on the right bank of the Vistula river (in the south-eastern part of Warsaw) where land rent is relatively lower and the availability of vacant grounds is still higher when compared to the western districts.

Concerning suburbanisation, migration towards the suburban zone of Warsaw increased already between 1990 and 1993, but attained higher values between 1994 and 1998. This process concerned especially the towns and communes neighbouring Warsaw (РотRYKowsKa, A. and ŚLEszÝ́sKi, P. 1999). 


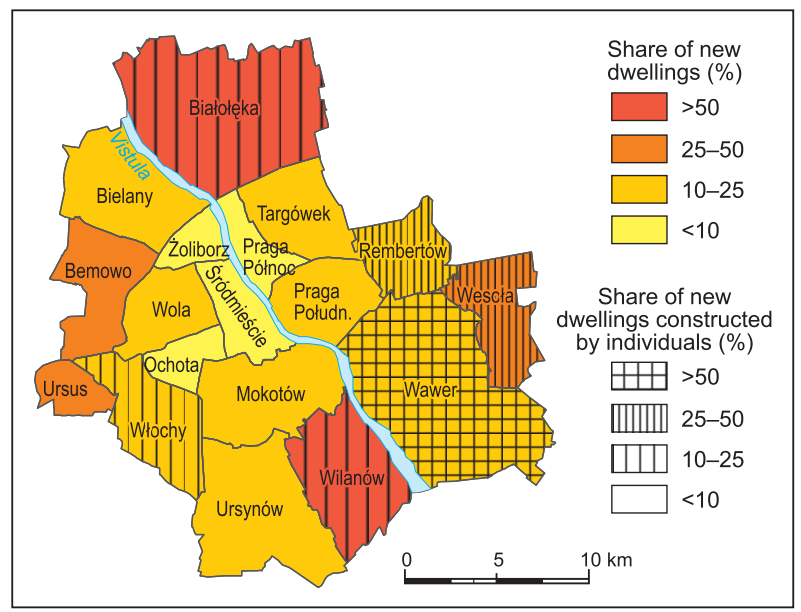

Fig. 5. The share of dwellings constructed between 2002 and 2012 in Warsaw by districts. Source: Local Data Bank, Central Statistical Office, 2014
In 1995 the outflow of people from Warsaw to other neighbouring communes constituted already $64 \%$ of all migrations in Warsaw; around $60 \%$ of this outflow was towards towns and communes situated on the left bank of the Vistula river (PotryKowsKA, A. and ŚLESZYŃSKI, P. 1999). In the following years (2000-2010), the positive migration rates were still in favour of close suburban communes (Scientific report Best Metropolises 2012).

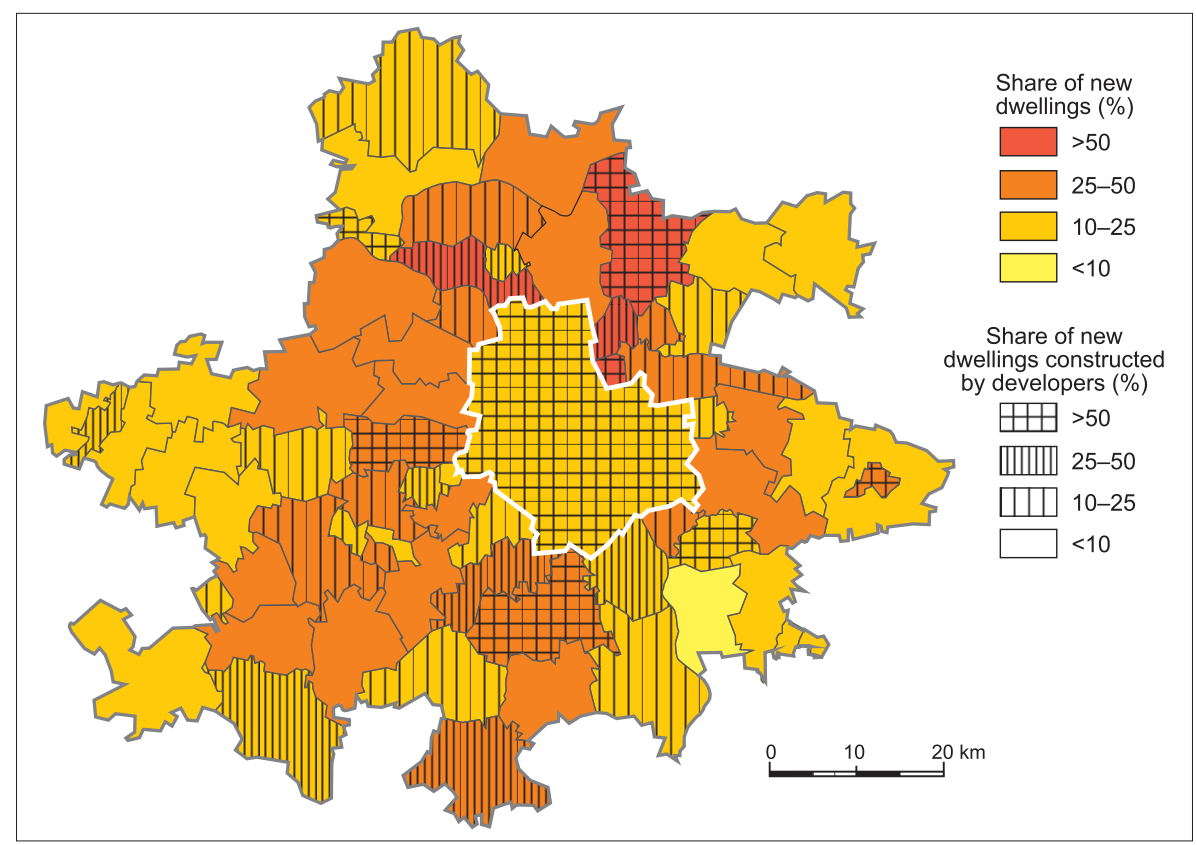

Fig. 6. The share of dwellings constructed between 2002 and 2012 in the Functional Urban Area of Warsaw by municipalities. Source: Local Data Bank, Central Statistical Office, 2014 
The current structure of actors providing new dwellings on the housing market impacts considerably residential mobility. Not only poor households but also those having average income are trapped in their actual place of residence, as dwellings offered by private developers dominate contemporary housing market in Warsaw. Under these circumstances residential moves become more and more difficult. For instance, young households with average income, whose parents are home-owners, are forced to develop their own residential strategy in order to acquire a dwelling. It may require both a change of hitherto inhabited district or moving out to a suburban area and lowering requirements in terms of quality and size of a dwelling. In many cases, parents financially support their children in purchasing a dwelling or building a new house.

The process of suburbanisation also generates changes in the social composition in the neighbouring municipalities, with growing concentration of middle and upper categories in the areas already having higher status during the socialist period. However, residential strategies differ among these two groups. The upper-class families who moved to better off suburban areas usually keep their apartments in the city in order to have a place of temporary accommodation in case they need to stay for a few days in the city (Bouloc, C. 2013).

\section{Conclusions}

In this paper changes in the social composition and socio-spatial pattern of Warsaw was analysed and compared to other Central European cities. To this end, particular attention was paid to the differentiation of new housing providers together with the process of suburbanisation, the regeneration of old housing through projects of rehabilitation and the process of property restitution. In general, certain similarities between the processes occurring in Warsaw and in other post-socialist cities were distinguished. Nevertheless, the thesis about differentiation among cities and countries in Central and Eastern Europe was confirmed (WĘCŁAWOWICZ, G. 1990). Although one may notice the growth of middle and upper social groups and their spatial concentration in the city, the mechanisms lying behind these processes are sometimes different in Warsaw when compared with other cities.

The increasing number of dwellings in suburban locations and the concentration of better off people in particular suburban neighbourhoods are similar to the processes occurring in other Central European cities. Undoubtedly, the process of suburbanisation will continue, but hardly any spectacular changes in the distribution of social groups can be expected as the socio-economic profile of municipalities in the close suburban zone has 
already been well established over the last 25 years. It seems that developers are more interested in quantity rather than quality, and in many cases the infrastructure accompanying new housing developments is inadequate to the number of households who arrive. This concerns also the transport infrastructure. Considering these inconveniences, more affluent households may decide to keep an apartment in the city centre rather than to move out to the suburban zone.

The process of 'socialist suburbanisation' still occurs within city limits, especially in the peripheral districts with the lowest density, while other districts undergo densification. Both processes may result in the process labelled as redevelopment (BouRNE, L.S. 1993) or 'new-build gentrification' as one of the mutations of gentrification (DAvidson, M. and LeEs, L. 2005) but certainly, not all of these newly constructed dwellings directly invoke this process.

Due to property restitution and privatisation of municipal dwellings, the social and economic status of owner-occupiers in Warsaw is quite diversified producing mixed ownership structures. What is more important, the ownership of a dwelling does not necessarily indicate higher economic status of a household. On the contrary, many buildings inhabited by owners suffer from gradual physical degradation.

The process of restitution of public buildings was delayed in Warsaw, mainly due to lack of legal framework. Lack of any specific measures and tools that would protect the sitting tenants (like it happened in other Central European countries) entails tensions and displacement and may also result in social upgrading of these areas. It seems that the impact of the restitution of private properties in Warsaw is underestimated, probably because of the lack of detailed statistical data. However, the consequences, both spatial and social might be important for the socio-spatial restructuring of the central districts of Warsaw. As renovation of old buildings takes place in several different pockets of the city this might increase their attractiveness which in turn might result in the growing influx of upper-middle class households, however, this process of social upgrading will most probably take various trajectories.

Together with privatisation and growing mix of ownership structures, the process of restitution of the private properties contribute to the process of fragmentation and social segregation at the micro-scale in the inner city of Warsaw. Even though regarding segregation indices these areas would be classified as socially mixed, yet, the overlapping layers of differentiations in certain districts may increase the tensions between different socio-economic groups. In addition, it may also create new challenges for local authorities e.g. how to address the needs of different social groups, and how to support the socially most fragile and weak groups in order to maintain existing social mix. 


\section{REFERENCES}

Baross, P. and Struyk, R. 1993. Housing transition in Eastern Europe, Progress and problems. Cities 10. (3): 179-188.

Blacksell, M. and Born, K.M. 2002. Private property restitution: the geographical consequences of official government policies in Central and Eastern Europe. The Geographical Journal 168. (2): 178-190.

Bodnar, J. and Molnar, V. 2010. Reconfiguring Private and Public: State, Capital and New Housing Developments in Berlin and Budapest. Urban Studies 47. (2): 789-812.

Bouloc, C. 2013. Les élites dans les villes polonaises. Etude de Géographie sociale. Dissertation, University of Paris 1. Warsaw, Institute of Geography and Spatial Organization Polish Academy of Sciences.

Bourne, L.S. 1993. The Demise of Gentrification? A Commentary and Prospective View. Urban Geography 14. (1): 95-107.

Clapham, D. 1995. Privatisation and the East European Housing Model. Urban Studies 32. (4-5): 679-694.

Czerwińska-JęDrusiak, B. 2009. Ludność i powierzchnia Warszawy w latach 1921-2008. Warszawa, GUS.

Davidson, M. and Lees, L. 2005. New-build 'gentrification' and London's riverside renaissance. Environment and Planning A, 37, 1165-1190.

Enyedi, Gy. 1992. Urbanisation in East Central Europe: Social Processes and Societal Responses in the State Socialist Systems. Urban Studies 29. (6): 869-880.

GórczyŃsKa, M. 2012a. Procesy zmian społecznych w przestrzeni Warszawy. Gentryfikacja, embourgeoisement czy redevelopment? In Procesy gentryfikacji w mieście. Ed. JАко́всZYк-GryszKiewicz, J. 25 ${ }^{\text {th }}$ Konwersatorium Wiedzy o Mieście. Łódź, Wydaw. UŁ, 245-255.

GóRCZYŃsKA, M. 2012b. Zmiany zróżnicowań społecznych i przestrzennych w wybranych dzielnicach Warszawy i aglomeracji paryskiej: dynamika i aktorzy. Doctoral dissertation, IGiPZ PAN, Université Paris I, Warszawa.

Górczyńska, M. 2014. Enjeux entre acteurs publics et privés dans le secteur de l'habitat à Varsovie: le cas des immeubles revendiqués. In Logement et politique(s), Eds. Belmessous F., Bonneval L., Coudroy de Lille, L. and Ortar L., l'Harmattan, collection "Habitat et société" (in print).

Herbst, I. and MuzioŁ-WęcŁawowicz, A. 1993. Housing in Poland, Problems and reforms. Cities 10. (3): 246-256.

Кок, Н. 1999. Migration from the city to the countryside in Hungary and Poland. GeoJournal 49. (1): 53-62.

Kovács, Z. 1994. A city at the crossroads: social and economic transformation in Budapest. Urban Studies 31. (7): 1081-1096.

Kovács, Z. 1999. Cities from state-socialism to global capitalism: an introduction, GeoJournal 49. (1): 1-6.

Kovács, Z. 2012. Residential Segregation in Budapest before and after Transition. In Residential segregation in comparative perspective. Eds. Maloutas, T. and Fujita, K. Burlington, Ashgate, Farnham, 197-215.

Kovács, Z., Wiessner, R. and Zischner, R. 2013. Urban Renewal in the Inner City of Budapest: Gentrification from a Post-socialist Perspective. Urban Studies 50. (1): 22-38.

Long-term Programme for housing stock management in Warsaw 2013-2017. Act XLVIII/1303/2012 from December 13, 2012. Retrived February 17, 2014 from http://bip.warszawa.pl/ NR/exeres/AB38E5DF-4A4D-448F-9E40-367AB33AB400,frameless.htm 
Lux, M. and Mikeszova, M. 2012. Property Restitution and Private Rental Housing in Transition: The Case of the Czech Republic. Housing Studies 27. (1): 77-96.

Lux, M., Kähriк, A. and Sunega, P. 2012. Housing Restitution and Privatisation: Both Catalysts and Obstacles to the Formation of Private Rental Housing in the Czech Republic and Estonia. International Journal of Housing Policy 12. (2): 137-158.

MarcińczaK, S., Gentile, M. and StęPniaK, M. 2013. Paradoxes of (post)socialist segregation: metropolitan sociospatial divisions under socialism and after in Poland. Urban Geography 34. (3): 327-352.

MarcińczaK, S., Musterd, S. and StęPniaK, M. 2012. Where the grass is greener: social segregation in three major Polish cities at the beginning of the $21^{\text {st }}$ century. European Urban and Regional Studies 19. (4): 383-403.

Pichler-Milanović, N. 1994. The role of housing policy in the transformation process of Central-East European cities. Urban Studies 31. (7): 1097-1115.

Pinçon, M. and Pinçon-Charlot, M. 1989. Dans les beaux quartiers. Paris, Edition du Seuil.

Potryкowska, A. and Śleszyński, P. 1999. Migracje wewnętrzne w Warszawie i województwie warszawskim, Atlas Warszawy, z. 7, IGiPZ PAN, Warszawa.

Raport o stratach wojennych Warszawy. 2004. Warszawa, Miasto Stołeczne Warszawa.

REIMANN, B. 1997. The transition from people's property to private property: consequences of the restitution principle for urban development and urban renewal in East Berlin's inner city residential areas. Applied Geography 17. 301-13.

Seleny, A. 2006. The Political Economy of State-Society Relations in Hungary and Poland, From Communism to the European Union, Cambridge, Cambridge University Press.

ŚLESZYŃSKI, P. 2004. Ksztattowanie się zachodniej części centrum Warszawy. Prace Geograficzne, 196, Instytut Geografii i Przestrzennego Zagospodarowania PAN, Warszawa.

Sме̨ткошsкi, M. 2009. Zróżnicowania społeczno-przestrzenne Warszawy - inercja czy metamorfoza struktury miasta? Przeglad Geograficzny 81. (4): 461-482.

Stępniak, M., Węceawowicz, G., Górczyńska, M. and Bierzyński A. 2009. Warszawa w świetle Narodowego Spisu Powszechnego 2002. Atlas Warszawy z. 11, Warszawa, IGiPZ PAN.

SÝкоRA, L. 1996. Economic and social restructuring and gentrification in Prague. Acta Facultatis Rerum Naturalium Universitatis Comenianae, Geographica 37. 71-81.

SÝкоRA, L. 1999. Changes in the internal spatial structure of post-communist Prague. GeoJoumal 49. (1): 79-89.

SÝ́KORA, L. 2009. New Socio-spatial formations: places of residential segregation and separation in Czechia. Tijdschrift voor Economische en Sociale Geografie 100. (4): 417-435.

SzelÉnyI, I. 1983. Urban Inequalities under State Socialism. New York. Oxford University Press.

TASAN, T. 1999. Warsaw under transformation: new tendencies in the housing market. GeoJournal 49. (1): 91-103.

WęcŁawowicz, G. 1990. The socio-spatial structure of the socialist cities in east-central Europe. In Urban and rural geography. Ed. Lando, F. Venice, Cafoscarina, 129-140.

WęCŁawowicz, G. 1998. Social Polarisation in Post-socialist Cities: Budapest, Prague and Warsaw. In Social Change and Urban Restructuring in Central Europe. Ed. EnYEDI, Gr., Budapest, Akadémiai Kiadó, 55-66.

WĘCŁAwowicz, G. 2002. Przestrzeń i społeczeństwo współczesnej Polski, studium z geografii społeczno-gospodarczej. Wydawnictwo Naukowe Warszawa, PWN, 